\title{
【教育講演 2】
}

\section{オーバーヘッドアスリートに対する関節鏡視下手術}

\author{
山門 浩太郎 \\ (福井総合病院スポーツ整形外科)
}

一般にスポーツ障害は, 繰り返し動作に起因する傷害 の積み重ねから生じるため治療に難渋することが多い が，投球障害に代表されるオーバーヘッドアスリートの 肩痛治療は特に難しい課題である。投球動作は肩関節に 多大な負荷を生じる運動であり，その角速度は7000/秒 にも達する. 投球動作は運動生理学上 6 相に分類される (ワインドアップ期, 早期コッキング期, 後期コッキング 期, 加速期, 減速期, フォロースルー期）が, 肩関節に対 する外旋負荷は後期コッキング期に最大となり，650 N に達する. また関節への圧迫力は $1000 \mathrm{~N}$ に, 引き抜きス トレスは950 Nまで増大するとされる。若年者の関節包 勒帯の破断強度が800 1200 N と報告されていることか らも, 肩関節障害がオーバーヘッドアスリートに頻発す る理由は理解できる。さらには，球速が上がれば上がる ほど肩関節に加わる負担も大きくなるため, 有望な若年 選手ほどケガのリスクも高くなることとなる.

関節鏡視下手術の誕生

競技者に対する手術には，手術の負担を最小化するた め, 多くは関節鏡視下手術が選択される。 5-10 $\mathrm{mm}$ 程 度の孔を 2 ～箇所程度作成して行う術式が膝のみなら ず肩でも一般的となっている.

記録に残る最も古い内視鏡による関節内部観察の試み は, デンマークの Nordentoftによってなされた. 1912年 にドイツ外科学会での発表はほとんど注目されず,また すぐに忘れ去られてしまったが,「arthroscopy (関節鏡)」 という単語がはじめて用いられたことは歴史的であっ た. 実用的な関節鏡は, 47年後の1959年に東京逓信病院 の渡辺正毅により日本で開発された。渡辺は1918年に 膀胱鏡を用いて屍体膝関節の観察を行った東京帝国大学 の高木憲次教授の門下生であり, 関節内部を照らすため のライトを装着するという発想は極めて独創的なもので あった，渡辺の業績は器械の開発にとどまらず，1957年 には鏡視下手術教科書の嗃矢となる関節鏡図説（Atlas of Arthroscopy) を出版するなど多岐にわたり，「近代関 節鏡の父」として広く称賛を受けている.

しかしながら，関節鏡手術が世界に広まるきっかけは， 1964年の Robert W. Jackson (カナダ) の東京訪問であっ た. Jacksonは彼の師であるIan Macnab教授から, ス
ペインの学会で発表された日本人の膝関節鏡の演題を聞 いて（教授は発表者の名前を覚えていなかったらしいの だが，渡辺の元を訪問した。 Jacksonによれば, 渡辺と いう人物を探しあてることに多大な努力を要したとのこ とである。渡辺は彼を温かくむかえ週 2 回の手術見学は 数ヶ月間続いたが, その見返りとして Jacksonは渡辺に 英語を教えたと記載している。膝関節鏡の有用性を確信 したJacksonは, カナダへの帰国に際して渡辺21号関節 鏡システムを 675 ドルで購入し持ち帰った。帰国した最 初の 1 年での症例数はわずか 25 例で, 彼は同僚医師から 奇異と嘲りの目をむけられたが, 手術数も徐々に増加し 数々の医師が彼の下で研修を積み全米各地で関節鏡手術 を行うようになった。現在の関節鏡視下手術の隆盛から すると考えにくいかもしれないが, 今日の発展は1960年 台の日本において一人の留学生と市井の整形外科医との 出会いから生まれたものである.

投球障害に対する手術治療

オーバーヘッド競技者の肩痛の原因として，外転外旋 位における腱板後外側部関節面と関節窩後上方部関節唇 の衝突（インターナルインピンジメント）が重要と考え られている。また，肩のゆるさといった一見異常とみな されうるオーバーヘッド競技者の特性は, オーバーヘッ ド動作の繰り返しに解剖構造が「適応 (adaptation)」し たものと解釈される. かつての手術治療は, インターナ ルインピンジメントが肩のゆるさゆえに生じていると考 えられ, ゆるさを解消する切開手術（すなわち脱臼に対 する制動術の応用）としてはじめられたが, 納得できる 競技復帰率が得られることはなかった。これは, 早いボー ルを投げるためには肩はゆるくなければならないため, 安定性を増した肩は投球において不利となってしまった ことが問題であった，現在の手術は，「適応」を生じた 肩の解剖構造を修復 (温存) することを重要視し, 具体 的な術式として, 腱板関節側と関節唇のほつれ (損傷部) の切除（クリーニング）が主として行われている。しか しながら，オーバーヘッドアスリートに対する手術の成 績は決して楽観的なものではなく, 現状においては疼痛 のため競技不能の肩をなんとか復帚できる程度に改善す るサルベージ手術とみなしうる。それでもなお手術を必 要とする競技者は存在し, 様々な成績向上の取り組みを 通じて，徐々にではあるが成績も向上しつつある. 